\title{
Long Term Nationwide Analysis of HIV and AIDS in Iceland, 1983-2012
}

Hlynur Indridason ${ }^{1}$, Sigurdur Gudmundsson ${ }^{1,2}$, Bergthora Karlsdottir ${ }^{2}$, Arthur Löve ${ }^{1,3}$, Haraldur Briem ${ }^{1,4}$ and Magnus Gottfredsson ${ }^{1,2^{*}}$

${ }^{1}$ Faculty of Medicine, School of Health Sciences, University of Iceland, Iceland

${ }^{2}$ Department of Infectious Diseases, Landspitali University Hospital, Iceland

${ }^{3}$ Department of Virology, Landspitali University Hospital, Iceland

${ }^{4}$ Directorate of Health, Reykjavik, Iceland

“Corresponding author: Magnus Gottfredsson, Landspitali University Hospital, Eirberg, 101 Reykjavik, Iceland, Tel: +354 543 1000; E-mail: magnusgo@landspitali.is Received date: October 13, 2014; Accepted date: November 24, 2014; Published date: November 28, 2014

Copyright: (c) 2014 Indridason $\mathrm{H}$, et al. This is an open-access article distributed under the terms of the Creative Commons Attribution License, which permits unrestricted use, distribution, and reproduction in any medium, provided the original author and source are credited.

\begin{abstract}
Introduction: Iceland is well suited for epidemiological research due to well-kept patient records, easy followup of patients and nation-wide health care databases. This study provides a nationwide 30-year epidemiological overview of the HIV epidemic in the country.
\end{abstract}

Materials and methods: Retrospective study on all HIV positive individuals in Iceland, 1983-2012. Clinical data, $\mathrm{CD}^{+} \mathrm{T}$-cell counts, plasma HIV RNA, proportion of late presenters and effectiveness of combined antiretroviral therapy (cART) were compared by different time intervals.

Results: In total, 313 were diagnosed with HIV in 1983-2012, thereof 222 (71\%) men and 91 (29\%) women. Most infections $(65 \%)$ were acquired outside the country. Mean incidence of HIV was $3.7 / 100,000$ inhabitants/year, with a significant increase in 2010-2012 ( $p=0.0113)$, related to misuse of the prescription drug methylphenidate among intravenous drug users. Official prescriptions for this drug increased from 3.5 in 2002 to 17.4 defined daily doses/ 1,000 inhabitants/day in 2012 . Mortality decreased by $70 \%$ during the study period $(p=0.0275)$. Proportion of late presenters decreased from $74 \%$ in the first decade to $36 \%$ during the third $(p=0.0001)$. After 6 months of ART, CD4 ${ }^{+}$ T-cells increased by only 26 cells/ $\mu$ l on average during the monotherapy era $(1987-1995 ; p=0,174)$, by 107 cells/ $\mu$ l during the early-cART era $(1996-2004 ; p<0.0001)$ and by 159 cells/ $\mu$ l during the late-cART era $(2005-2012$; $\mathrm{p}<0,0001)$. Similarly, progressively greater reductions in plasma HIV RNA were observed from 1996-2004 to 2005-2012 ( $p<0.0001)$.

Conclusions: HIV incidence remained relatively low in Iceland until 2010, when it increased significantly due to spread among IDUs. The majority of HIV infections diagnosed in Iceland were imported. With ever more effective drug treatments on CD4+ T-cells and plasma HIV RNA, the number of AIDS diagnoses and deaths has decreased dramatically.

Keywords: HIV; Iceland; Epidemiology; Injection drug users; Men who have sex with men; Late presenters; Antiretroviral therapy

\section{Introduction}

The first cases of the acquired immunodeficiency syndrome, or AIDS, were described in 1981 in the US [1,2]. HIV was isolated in 1983 [3] and the first HIV positive blood samples in Iceland are from the same year [4]. As of 2012, over 70 million people have become infected, of which over 35 millions have died due to AIDS [5]. SubSaharan Africa has been the most severely affected geographical area, containing $69 \%$ of the people living with HIV worldwide. In Europe, it is estimated that more than 1.5 million people are infected and more than 1.1 million in the US [6]. Epidemiological studies suggest that despite advances in diagnosis and treatment, HIV incidence has been on the rise in Eastern-Europe in the past few years [5], whereas the incidence has dropped by over $30 \%$ in the US from 2002 to 2011 [7]. Antiretroviral drugs have been the basis of HIV treatment since the first nucleoside reverse transcriptase inhibitor was introduced in 1987 [8], followed by other antiretrovirals, and in 1996 by combined Antiretroviral Therapy (cART) [9]. Furthermore, new methods to monitor plasma HIV RNA as well as drug resistance tests on viruses have greatly facilitated treatment-related decisions [10,11]. At the present time newly infected HIV-positive individuals who enjoy good health care can have a comparable life expectancy to those in the same age group in the general population $[12,13]$. However, HIV infected individuals are still at risk of getting opportunistic infections and other complications [14], especially Late Presenters (LP) or those who receive inadequate therapy $[15,16]$.

Migrants with HIV are a growing population in many Western European countries, especially those with an HIV infection acquired through heterosexual transmission originated from sub-Saharan Africa, Asia and the Caribbean [17-19]. In 2011, over half of all new HIV diagnoses were among migrants in Sweden, Norway, Finland and the UK.

Men who have Sex with Men (MSM) have been one of the most important risk groups for HIV infection since the early 1980s. Epidemics of HIV among MSM have resurfaced in many countries despite improved treatment, education and prevention strategies $[5,20-22]$. Health authorities have made it a priority to target this and 
Page 2 of 7

other key populations in an effort to slow the spread of the global epidemic [22].

Iceland is ideally suited for epidemiological studies, with good record keeping and government-based health care. Only a few studies exist on HIV in Iceland, one of which was an overview of the first 10 years of the epidemic [23]. At that time the incidence of AIDS in the country was 1.36 per 100.000 /year, with a mean survival of only 22 months following the diagnosis. MSM were the most common risk group while infections in IDU were only sporadic. Subsequently, the proportion of HIV diagnoses among migrants has increased, with corresponding changes in viral serotypes $[19,24]$.

All permanent residents of Iceland have access to governmentfunded health care and medical care to HIV positive patients has been provided free of charge from the onset of the epidemic. The aims of this study were to give a nationwide overview of HIV during the first 30 years in Iceland, 1983-2012. The incidence of HIV and AIDS, clinical characteristics and risk groups were described and compared. Furthermore, $\mathrm{CD} 4^{+} \mathrm{T}$-cell counts and plasma HIV RNA were analysed in the context of ART (antiretroviral therapy) from the beginning of the epidemic in this unselected nationwide cohort.

\section{Methods}

\section{Setting, diagnosis and recording of HIV}

Iceland had 235,537 inhabitants in the beginning of 1983 and 321,857 at the end of 2012 [25]. All diagnoses of HIV in Iceland are performed in a central virology laboratory using ELISA and Western blot for confirmation according to standard CDC protocols and definitions; the disease is reportable to the Director of Health in Iceland. HIV patients who reside in Iceland get their clinical care from the Department of infectious diseases at Landspitali University Hospital. A comprehensive list of HIV patients was generated by searching the clinical and virology databases at the University Hospital and cross-referencing with data at the Directorate of Health for the period 1983-2012. Data on methylphenidate use in the country was obtained from The Icelandic Medicines Agency. The study was approved by the Landspitali Bioethics committee (ref 45/2012) and registered at the Data Protection Agency of Iceland (ref 2012111366HGK/--).

\section{Review of clinical data}

Medical records of all HIV positive individuals who had been diagnosed, treated and/or monitored at the National University Hospital of Iceland were reviewed. The information included age at diagnosis, gender, country of origin, risk group, origin of infection, time of diagnosis, AIDS-defining condition, ART (medications and dates of treatment), laboratory results (plasma HIV RNA and CD4 ${ }^{+} \mathrm{T}$ cell count) and outcomes. Vital status of patients was checked using the national registry of citizens (Registers Iceland). The definition of AIDS used in this study was based on European guidelines, which require an AIDS-defining condition to be diagnosed for that individual to be diagnosed with AIDS [26]. Persons presenting with $\mathrm{CD} 4^{+} \mathrm{T}$-cell counts $<350$ cells/ $\mu$ l or an AIDS-defining condition at the time of HIV diagnosis are called late presenters (LP) [27]. For epidemiologic analysis the study period was divided into three 10 -year intervals (decades I,II and III).

\section{Effectiveness of ART}

Effectiveness of ART in this unselected cohort was compared using plasma HIV RNA and $\mathrm{CD}^{+}{ }^{+}$T-cell count in ART naive HIV patients before and after approximately 6 months of treatment as an endpoint. To compare treatment effects, three time periods were compared; monotherapy era (1987-1995); early cART era (1996-2004); and late cART era (2005-2012). Data of plasma HIV RNA were only available from 1996.

\section{Statistical analysis}

To calculate incidence and mortality, population figures from Statistics Iceland (Hagstofa Islands) [25] were used. For statistical comparisons the unpaired and paired t-tests as well as the chi-square test were used as appropriate, with a two tailed p-value of $<0.05$.

\section{Results}

\section{Epidemiology}

Overall, 313 individuals were diagnosed with HIV in Iceland between January 1, 1983 and December 31, 2012, of which 222 (71\%) were male and 91 (29\%) were female. At the end of 201262 had died, of which 39 (14\% of HIV positive individuals who stayed at least 12 months in the country) died due to AIDS. During the observation period 75 individuals left permanently or moved from the country, 41 of whom had stayed in the country for less than 12 months after HIV diagnosis. At the end of 2012, 176 individuals were receiving active care, thereof $34 \%$ women and $66 \%$ men.

\begin{tabular}{|c|c|c|c|c|}
\hline \multicolumn{1}{|c|}{ Gender } & $\begin{array}{c}\text { I: 1983 - } \\
\mathbf{1 9 9 2}\end{array}$ & $\begin{array}{c}\text { II: 1993 - } \\
\mathbf{2 0 0 2}\end{array}$ & III: 2003 - 2012 & Total \\
\hline Number of men & $76(88 \%)$ & $61(69 \%)$ & $85(61 \%)$ & $\begin{array}{c}222 \\
(71 \%)\end{array}$ \\
\hline $\begin{array}{c}\text { Number of } \\
\text { women }\end{array}$ & $10(12 \%)$ & $27(31 \%)$ & $54(39 \%)$ & $91(29 \%)$ \\
\hline Total & $86(27 \%)$ & $88(28 \%)$ & $139(44 \%)$ & 313 \\
\hline
\end{tabular}

Table 1: Distribution of new HIV diagnoses by gender in three 10-year time periods.

The mean age at diagnosis was 34.9 years (range: $2-78$ years). The largest age group was $26-35$ years, comprising $40 \%$ of all diagnosed with HIV. An overview of basic epidemiologic parameters by study decades is shown in Table 1 . There was a marked increase in the number of new diagnoses in the third decade of the study compared to the first one $(p=0.0004)$. Numbers of new HIV diagnoses in women increased both relatively and absolutely, from $10(12 \%)$ in the first decade to $54(39 \%)$ in the third $(\mathrm{p}<0.0001)$. The annual incidence of HIV infection, expressed as number of new diagnosed infections per 100,000 inhabitants is shown in Figure 1A. During the entire period it was 3.7 on average, 2.1 in women and 5.3 in men. During the study period 69 patients were diagnosed with AIDS (22\% of all HIV positive individuals), 16 women ( $18 \%$ of all women) and 53 men ( $24 \%$ of all men); 20 were foreign born ( $17 \%$ of all foreign-born HIV positive persons). The mean age at diagnosis was 40 years (range: $18-77$ years). The annual incidence of AIDS is shown in Figure 1B; and the annual mortality from AIDS is shown in Figure 1C. During the study 62 deaths were recorded of which 39 listed AIDS as the cause of death or 
Citation: Indridason H, Gudmundsson S, Karlsdottir B, Löve A, Briem H, et al. (2014) Long Term Nationwide Analysis of HIV and AIDS in Iceland, 1983-2012. J AIDS Clin Res 5: 387. doi:10.4172/2155-6113.1000387

Page 3 of 7

$57 \%$ of all patients receiving an AIDS diagnosis in the country. The other 24 individuals died of various other causes, such as heart diseases and cancers not believed to be related to HIV. The mean age at death due to AIDS was 42.3 years (range: $22-79$ years.) The incidence of death from AIDS was 0.47 per 100,000 inhabitants per year. A significant decrease in mortality from AIDS was noted, from 0.71 in the first half of the study to 0.22 in the second half ( $\mathrm{p}=0.0275$ ). Only 5 women died from AIDS (31\% of all women diagnosed with AIDS) and 35 men ( $66 \%$ of all men diagnosed with AIDS).

\section{A) HIV incidence in Iceland, 1983-2012}

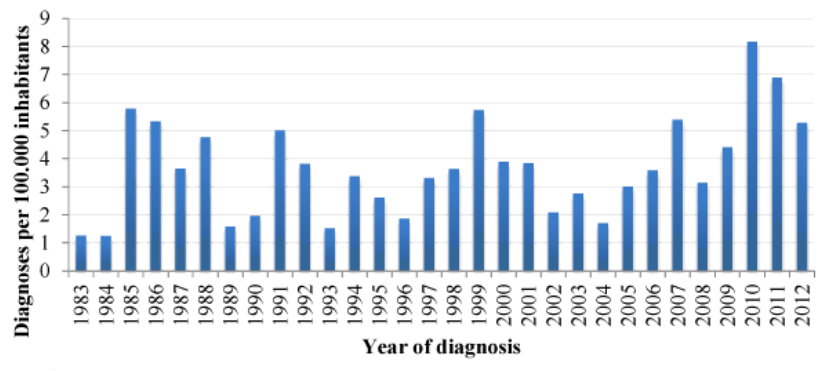

B)

AIDS incidence in Iceland, 1983-2012

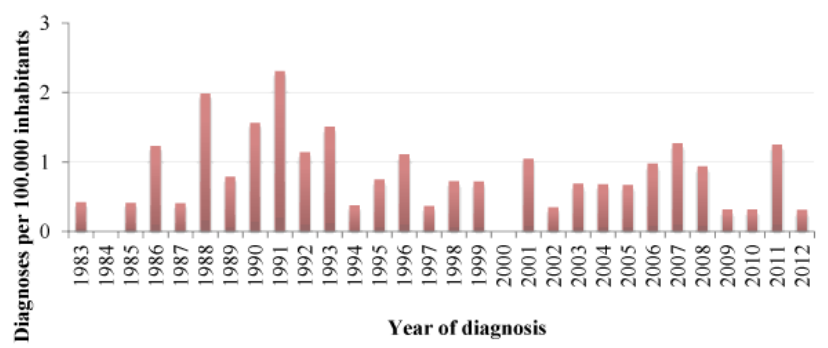

\section{C) AIDS mortality in Iceland,} 1983-2012

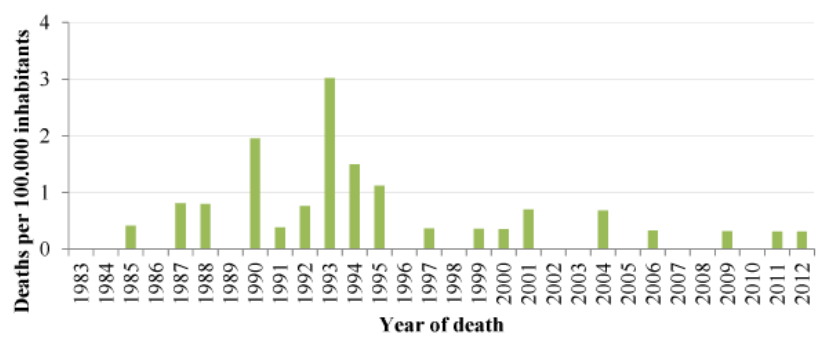

Figure 1: A) HIV incidence, B) AIDS incidence and C) mortality due to AIDS from 1983 to 2012 (per 100.000 inhabitants) in Iceland.

\section{Origins and risk groups}

The associations between risk groups, country of birth (native vs foreign-born) and probable country of infection (Iceland vs other countries) in the patient cohort is shown in Table 2. As shown, 192 (61\%) of the HIV positive population were born in Iceland while 121 (39\%) were foreign-born. A minority of the women (44\%) were born in Iceland while $68 \%$ of the men were native Icelanders. Of the 248 individuals where information was available regarding probable country of infection, $35 \%$ became infected in Iceland and $65 \%$ elsewhere. Of the 86 who likely became infected in Iceland only 7 were foreign-born (8\%). Almost half of all Icelanders with a documented origin of infection became infected outside the country (43\%) whereas the vast majority (94\%) of foreign-born individuals contracted HIV abroad.

\begin{tabular}{|c|c|c|c|c|c|}
\hline \multirow[b]{2}{*}{ Risk group } & \multirow[b]{2}{*}{$\begin{array}{l}\text { Country of } \\
\text { origin }\end{array}$} & \multicolumn{4}{|c|}{ Origin of infection } \\
\hline & & Iceland & Other & Unknown & Total \\
\hline \multicolumn{6}{|l|}{ Men } \\
\hline \multirow[t]{2}{*}{ MSM } & Iceland & 24 & 23 & 36 & 83 \\
\hline & Other & 2 & 12 & 4 & 18 \\
\hline \multirow[t]{2}{*}{ IDU } & Iceland & 22 & 2 & 4 & 28 \\
\hline & Other & 1 & 9 & 2 & 12 \\
\hline \multirow{2}{*}{$\begin{array}{l}\text { Heterosexual } \\
\text { intercourse }\end{array}$} & Iceland & 7 & 18 & 3 & 28 \\
\hline & Other & 2 & 8 & 1 & 11 \\
\hline \multirow[t]{2}{*}{ Other ${ }^{*}$} & Iceland & 0 & 6 & 7 & 13 \\
\hline & Other & 0 & 26 & 3 & 29 \\
\hline Total, men & & 58 & 104 & 60 & 222 \\
\hline \multicolumn{6}{|l|}{ Women } \\
\hline \multirow[t]{2}{*}{ IDU } & Iceland & 13 & 1 & 0 & 14 \\
\hline & Other & 1 & 1 & 0 & 2 \\
\hline \multirow{2}{*}{$\begin{array}{l}\text { Heterosexual } \\
\text { intercourse }\end{array}$} & Iceland & 10 & 9 & 1 & 20 \\
\hline & Other & 1 & 36 & 1 & 38 \\
\hline \multirow[t]{2}{*}{ Other* } & Iceland & 3 & 1 & 2 & 6 \\
\hline & Other & 0 & 10 & 1 & 11 \\
\hline Total, women & & 28 & 58 & 5 & 91 \\
\hline \multicolumn{2}{|c|}{ Total, men and women } & 86 & 162 & 65 & 313 \\
\hline
\end{tabular}

Table 2: Number of new HIV diagnoses by sex, risk groups, country of origin and origin of infection. MSM=Men who have Sex with Men. IDU: Injection Drug Users. ${ }^{*}$ Other risk groups: Infection by blood products; from mother to child or unknown.

Information was available regarding probable mode of infection in 260 individuals, most commonly male homosexual (39\%) and heterosexual intercourse (37\%). A majority (74\%) of infections in IDU took place domestically while $43 \%$ of MSM and $22 \%$ of those infected by heterosexual intercourse contracted the virus within Iceland.

The temporal associations between HIV diagnoses in Iceland by risk groups and country of birth are shown in Figure 2. As shown, close to $80 \%$ of HIV positive individuals diagnosed before the year 2000 were born in Iceland but subsequently the proportion of foreignborn persons has increased steadily, mostly in persons infected by heterosexual intercourse. 
Five infections by blood products were documented, of which 3 reportedly took place in Iceland (retrospectively diagnosed in blood samples in 1985, 1986, 1989) and two elsewhere (reported in 1990 and 2011 in Iceland).

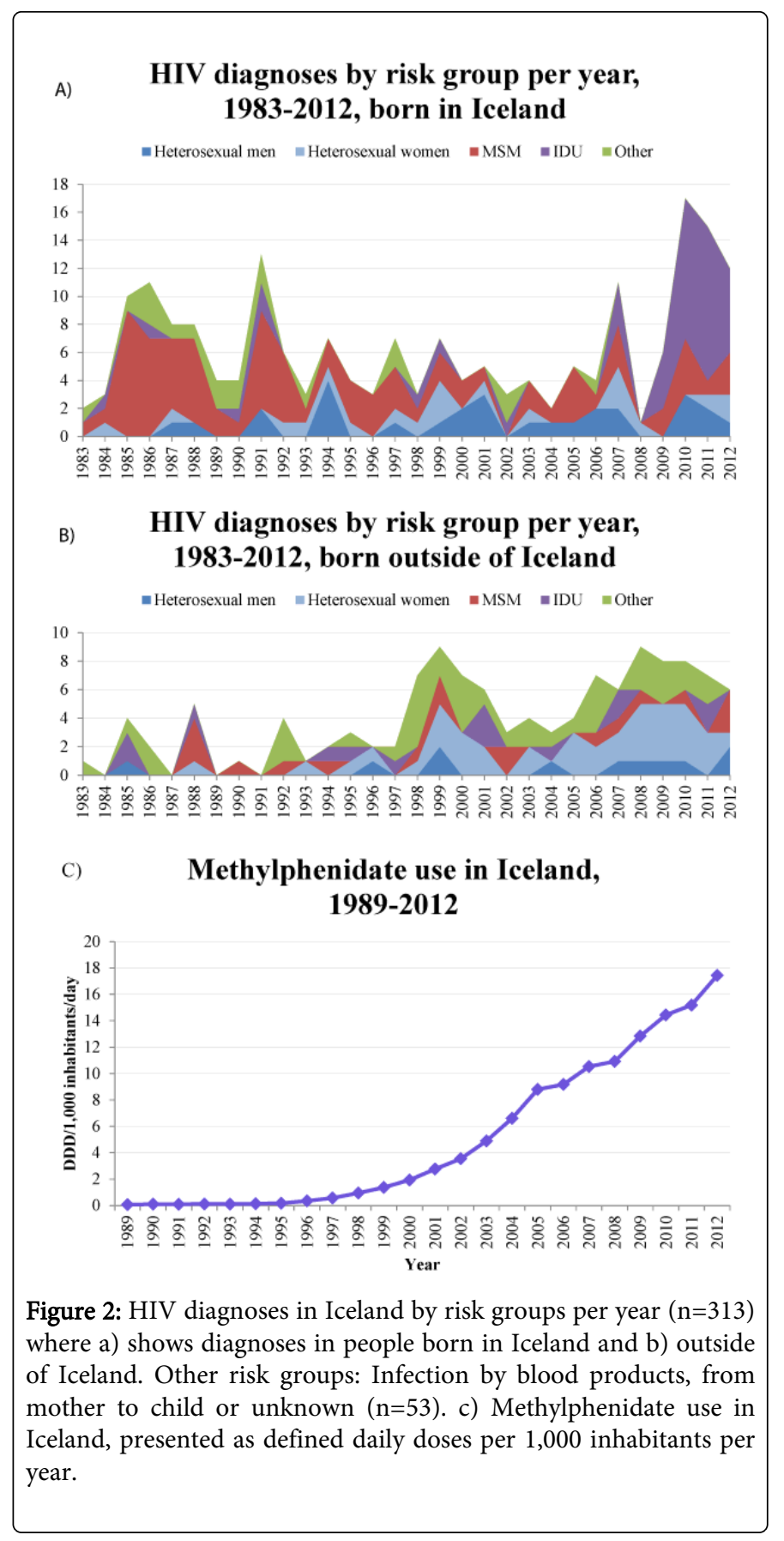

\section{Outbreak in IDU population}

At the end of 2012, 21.5\% of all HIV positive individuals who have received care in Iceland reportedly contracted the virus by IDU, most of which were related to an outbreak which probably started in 2007, followed by a dramatic increase in 2009-2012 (Figure 2). From 2007, 38 HIV infections in this group were diagnosed. Six of those individuals have died (causes unrelated to HIV) and one has moved from the country, leaving 31 of them in active care. Of the HIV positive IDU since 2007 , the median $\mathrm{CD} 4^{+} \mathrm{T}$-cell count at diagnosis was 600 cells $/ \mu$ l. Seven of them (18\%) were late presenters and two had no known $\mathrm{CD}^{+} \mathrm{T}$-cell count near the time of diagnosis. The most commonly used or preferred IV drug in this group was methylphenidate, used by at least $87 \%$ before the time of diagnosis. Figure $2 \mathrm{C}$ shows the increase in prescribed methylphenidate use in Iceland in defined daily doses (DDD) per 1,000 inhabitants per day. It increased from 3.5 in 2002 to $17.4 \mathrm{DDD} / 1,000$ inhabitants/day in 2012. In total, 23 of this group were receiving cART as of July 2014 (74\% of IDU in active care). The median most recent $\mathrm{CD} 4^{+} \mathrm{T}$-cell count of those IDU who have been receiving cART was 544 cells/ $\mu \mathrm{l}$, from a median of $467 \mathrm{cells} / \mu \mathrm{l}$ at the time of diagnosis $(\mathrm{p}=0.1364)$. In the same group, 19 (83\%) had plasma HIV RNA levels of less than 50/ml in their most recent measurement.

\section{$\mathrm{CD4}^{+} \mathrm{T}$-cell counts at diagnosis and late presenters}

Fairly comprehensive data regarding $\mathrm{CD} 4^{+} \mathrm{T}$-cell counts at the time of diagnosis was available for the last two decades of the study, 1993-2012. An increase was noted from a median cell count of 355 in the second decade to 499 in the third. At least 104 patients $(53 \%$ of those with a documented $\mathrm{CD} 4^{+} \mathrm{T}$-cell count within 6 months from diagnosis) were LP (with $<350 \mathrm{CD} 4^{+} \mathrm{T}$-cells/ $\mu$ l and/or AIDS). Only $12 \%$ of LP presented with AIDS. The proportion of LP, of those with a documented $\mathrm{CD}^{+}$T-cell count, decreased from $74 \%$ in the first decade to $65 \%$ in the second and $36 \%$ in the last $(p=0.0001)$. The proportion of LP among IDU was 23\%, among heterosexuals 55\% and among MSM 51\%. Foreign-born LP were 36 (35\%) in total.

\section{Effectiveness of cART}

At the end of 2012, $82 \%$ of active patients were receiving cART in Iceland. Of those who had received cART for 6 months or more $91 \%$ had undetectable levels of plasma HIV RNA. The effect of antiviral therapy on plasma HIV RNA and $\mathrm{CD}^{+}$T-cell count by the three study periods is summarized in Table 3 . The increase in $\mathrm{CD} 4^{+} \mathrm{T}$-cell count was not significant during the monotherapy era, but following the early adoption of cART a significant increase was noted, with even furher improvements during the most recent period (late cART-era). Similar results were observed with respect to plasma HIV RNA measurements. An average decrease of $2.19 \log (\mathrm{p}<0.0001)$ was noted after 6 months of treatment during the early cART era while the decrease was $3.20 \log (\mathrm{p}<0.0001)$ during the late $\mathrm{cART}$ era. Undetectable HIV RNA, defined as less than 50 copies/ml was observed among $57 \%$ of patients reveiving antiviral therapy during the early cART era, while this goal was subsequently achieved among $85 \%$.

\section{Discussion}

This study encompasses all known cases of HIV in Iceland in 30 years, providing a detailed analysis of changes during an unusually long observation period in an unselected nationwide cohort. We demonstrate that HIV incidence remained relatively low and stable in Iceland from the beginning of the epidemic until 2010-2012 when an outbreak occurred among IDU. In this respect it contrasts with the trends in most other western countries where HIV incidence has generally been stable or decreasing [5]. In the United States the annual incidence of HIV has been relatively stable or slightly decreasing but it has been considerably higher than in Iceland, close to 20/100,000 for most of the 2000s $[7,20,28,29]$. Historically, the Nordic countries have had a low incidence of HIV compared to most other countries in 
Europe. Over the past decade the annual incidence of HIV has ranged from 4-6/100.000 inhabitants in Norway, Denmark and Sweden [30-32]. On average, the incidence has been lowest in Iceland and Finland among the Nordic countries [33] while in Greenland it has been highest, although it has seen a slow decline in recent years [34].

A big proportion of new HIV patients in the Nordic countries are foreign-born. In Sweden this was the case for at least $71 \%$ of all people reported with a new HIV infection in 2010 and 2011 [32]. Most of them were infected heterosexually prior to arriving in Sweden but the MSM population still accounts for the largest proportion of new cases domestically. Data from Denmark for 2012 shows that about 50\% of new HIV diagnoses were among tourists and immigrants, while over half became infected outside of Denmark for the first time in over 10 years [31]. In Finland, over half of new HIV patients in 2011, for the first time, were foreign-born and overall HIV incidence per 100,000 increased slightly from 2000 , being 2.8 in 2000 compared to 3.6 in 2010 [33]. In Norway, most HIV patients infected sexually are immigrants and while new HIV cases in MSM declined a bit yearover-year in Norway in 2012, they increased again in 2013 [30]. Thus, foreign-born HIV patients are increasingly becoming a bigger part of the HIV epidemic in the Nordic countries but the domestic MSM population remains very important. In fact, even after many years of research and prevention efforts, high prevalence and incidence of HIV has been reported in MSM around the world [35]. In many highincome countries, such as Australia, the UK, France, and the USA, overall HIV incidence trends are declining except in MSM, in what has been described as re-emergent epidemics. In large parts of Africa, Asia, and Latin America, the highest rates of HIV infection in any risk group are in these men. Due to the resilient nature of the epidemic in MSM and other key populations globally, including IDU, the World Health Organization recently released new guidelines on HIV prevention, diagnosis, treatment and care to try to combat the epidemic more effectively [22].

\begin{tabular}{|c|c|c|c|c|c|}
\hline \multirow[b]{2}{*}{ Time period } & \multirow[b]{2}{*}{$\begin{array}{c}\text { Number } \\
\text { of ART } \\
\text { naïve } \\
\text { who } \\
\text { received } \\
\text { ARTa }^{\text {a }}\end{array}$} & \multicolumn{2}{|c|}{$\mathrm{CD}^{+} \mathrm{T}$-cell count } & \multicolumn{2}{|c|}{ Plasma HIV RNA } \\
\hline & & $\begin{array}{c}\text { Mean } \\
\text { before } \\
\text { first ART, } \\
\text { cells/ } / \mu l\end{array}$ & 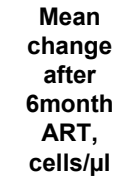 & $\begin{array}{c}\text { Mean } \\
\text { before } \\
\text { first ART, } \\
\text { log }\end{array}$ & $\begin{array}{c}\text { Mean } \\
\text { change } \\
\text { after } 6 \\
\text { month ART, } \\
\quad \text { log }\end{array}$ \\
\hline $\begin{array}{c}\text { Monotherapy } \\
\text { era } \\
(1987-1995)\end{array}$ & 47 & $\begin{array}{c}266 \\
(192 ; 339)\end{array}$ & $26(-28 ; 81)$ & $N / A^{b}$ & $N / A^{b}$ \\
\hline $\begin{array}{c}\text { Early cART } \\
\text { era } \\
(1996-2004)\end{array}$ & 66 & $\begin{array}{c}275 \\
(223 ; 326)\end{array}$ & $\begin{array}{c}107 \\
(71 ; 143)^{*}\end{array}$ & $\begin{array}{c}4,35 \\
(4,12 ; 4,59)\end{array}$ & $\begin{array}{c}-2,19 \\
(-2,51 ; 1,87)^{*}\end{array}$ \\
\hline $\begin{array}{c}\text { Late cART } \\
\text { era } \\
(2005-2012)\end{array}$ & 78 & $\begin{array}{c}295 \\
(223 ; 367)\end{array}$ & $\begin{array}{c}159 \\
(129 ; 189)^{*}\end{array}$ & $\begin{array}{c}4,67 \\
(4,46 ; 4,87)\end{array}$ & $\begin{array}{c}-3,20 \\
(-3,46 ;-2,93)^{*}\end{array}$ \\
\hline Total & 191 & & & & \\
\hline
\end{tabular}

Table 3: The effect of ART on ART-naïve individual's plasma HIV RNA and CD4 ${ }^{+}$T-cell count. 95\% confidence interval in parentheses. *Significant change $(\mathrm{p}<0.0001)$.


who have not received ART previously for more than 5 months. bPlasma HIV RNA measurements not done before 1996.
Many similarities can be seen between the results of this long-term nationwide study and global trends in HIV in other affluent societies, including the increasing proportion of women and imported cases [17]. It should be noted however that many of the foreign-born individuals had already been diagnosed and sometimes treated elsewhere before moving to Iceland. In the last years of the study period MSM still remain one of the most important risk groups in the country, surpassed in numbers only by IDU due to the outbreak of 2009-2012. Recent data show, however that the spread in IDU has subsided while the number of new infections in MSM remains relatively high and may even be increasing [4]. Although drug users may pose a challenge to the health care system due to medical noncompliance and no-shows in the clinics, our data suggest that most of them may be started on ART with good treatment results if they receive regular reminders and positive reinforcement, even in the setting of continued drug use. Since 2010, early initiation of cART has been recommended to most HIV infected IDU, irrespective of CD4+ T-cell count, to reduce risk of further spread (treatment as prevention). The outbreak among the IDU in Iceland has since subsided, which is not unexpected, since outbreaks in this population tend to be relatively short lived [36]. Other Nordic nations experienced similar outbreaks many years earlier, such as Finland in 1998 [37] while Denmark, Norway and Sweden all experienced similar outbreaks around the mid 1980s where HIV incidence in IDU fell as sharply as it rose after about 2-4 years [36]. Interestingly, while many of the HIV positive IDU in Iceland used multiple IV drugs, the most popular one was the psychostimulant prescription drug methylphenidate, but heroin and amphetamine were the most common ones in Denmark, Norway and Sweden [36]. Most IDU who use methylphenidate inject themselves frequently due to the short halflife $[38,39]$, thus increasing the risk of sharing needles. Additionally, IV methylphenidate use has been associated with worse pulmonary morbidity and mortality compared to IV heroin and cocaine use [39].

The results of this study underline the benefits of increasingly effective cART. Moreover, comparisons on CD4+ T-cell counts at the time of diagnosis suggests that patients in Iceland are generally being diagnosed earlier and thus interventions to reduce spread can be made earlier. Consequently, the number of new AIDS cases and deaths due to AIDS have decreased dramatically.

The proportion of HIV-infected individuals who present late, and thus have higher morbidity, mortality risk and infectivity compared to others [40-42], has remained high over the past decade in Western Europe [43]. LP represent as much as 50\% of all HIV patients in many Western-European countries [43-47], a proportion that could likely be lowered with more effective testing and earlier entry into care $[48,49]$. In particular, we feel that more targeted education and screening among MSM in Iceland would be warranted, given the high proportion of LP in this group. Late presentation of HIV infection is not just a problem of the past. The results of this study show that the proportion of LP of all new HIV diagnoses has decreased significantly and is much lower in recent years than in Sweden for example, where about $60 \%$ of new HIV diagnoses in 2011 were LP, the majority of which were heterosexual immigrants [32]. The part of the HIV positive population that remains unaware of their infection is very important since close to half of all new HIV transmission events are believed to be originated from that group $[41,50]$. It is also important to note that universal screening has been advocated in settings where the seroprevalence of HIV infection exceeds $0.1 \%$ [51], which is not the case in Iceland. 
This study has some limitations due to its retrospective nature, mostly due to lack of information, especially from the early years of the epidemic. Additionally, the number of undiagnosed HIV positive individuals in Iceland has not been estimated, but this might add $20 \%$ to the known HIV positive population $[41,50]$.

In summary, the annual incidence of HIV infection remained relatively low in Iceland from the early days of the epidemic until 2010, when it increased significantly due to an outbreak among IDU related to methylphenidate use, which has now subsided. Most IDU can be treated effectively with ART. Our study shows that MSM remain the most important risk group for HIV infection within the domestic population, suggesting that more educational and preventive efforts are needed. The proportion of late presenters has steadily decreased. In addition, with ever more effective drug treatments on $\mathrm{CD} 4^{+} \mathrm{T}$-cells and plasma HIV RNA, the number of AIDS diagnoses and deaths has decreased dramatically.

\section{Acknowledgement}

H.I. conducted data analysis and collection, and wrote the article. S. G., B.K., A.L. and H.B. assisted in data collection and writing of the article. M.G. designed the study, wrote the article, and assisted in data collection and analysis. We are grateful to Sveinn Gudmundsson, Gudrun Erna Baldvinsdottir, Gerdur Helgadottir, Inga Skaftadottir and Juliana Hedinsdottir for their help with finding data, references and insightful discussions. This research was supported by grants from the University of Iceland Research Fund and by Gilead Nordic fellowship.

\section{References}

1. Centers for Disease Control (CDC) (1981) Kaposi's sarcoma and Pneumocystis pneumonia among homosexual men--New York City and California. MMWR Morb Mortal Wkly Rep 30: 305-308.

2. Centers for Disease Control (CDC) (1981) Pneumocystis pneumonia-Los Angeles. MMWR Morb Mortal Wkly Rep 30: 250-252.

3. Barré-Sinoussi F, Chermann JC, Rey F, Nugeyre MT, Chamaret S, et al. (1983) Isolation of a T-lymphotropic retrovirus from a patient at risk for acquired immune deficiency syndrome (AIDS). Science 220: 868-871.

4. http://www.landlaeknir.is/um-embaettid/greinar/grein/item22112/HIV/ Alnaemi-31-12-2013

5. UNAIDS (2012) Report on the global AIDS epidemic.

6. Centers for Disease Control and Prevention (2013) Monitoring selected national HIV prevention and care objectives by using HIV surveillance data-United States and 6 dependent areas-2011. HIV Surveillance Supplemental Report 18.

7. Johnson AS, Hall HI, Hu X, Lansky A, Holtgrave DR, et al. (2014) Trends in diagnoses of HIV infection in the United States, 2002-2011. JAMA 312: 432-434.

8. Fischl MA, Richman DD, Grieco MH, Gottlieb MS, Volberding PA, et al. (1987) The efficacy of azidothymidine (AZT) in the treatment of patients with AIDS and AIDS-related complex - A double-blind, placebocontrolled trial. N Engl J Med 317: 185-191.

9. Collier AC, Coombs RW, Schoenfeld DA, Bassett RL, Timpone J, et al. (1996) Treatment of human immunodeficiency virus infection with saquinavir, zidovudine, and zalcitabine. AIDS Clinical Trials Group. N Engl J Med 334: 1011-1017.

10. Mellors JW, Rinaldo CR, Gupta P, White RM, Todd JA, et al. (1996) Prognosis in HIV-1 infection predicted by the quantity of virus in plasma. Science 272: 1167-1170.

11. Blum RA, Wylie N, England T, French C (2005) HIV resistance testing in the USA--a model for the application of pharmacogenomics in the clinical setting. Pharmacogenomics 6: 169-179.
12. van Sighem AI Gras LA, Reiss P, Brinkman K, de Wolf F; ATHENA national observational cohort study (2010) Life expectancy of recently diagnosed asymptomatic HIV-infected patients approaches that of uninfected individuals. AIDS 24: 1527-1535.

13. Antiretroviral Therapy Cohort Collaboration (2008) Life expectancy of individuals on combination antiretroviral therapy in high-income countries: a collaborative analysis of 14 cohort studies. Lancet 372: 293-299.

14. Miller Vabin CA, Phillips AN, Rottmann C, Rabenau H (2000) The impact of protease inhibitor-containing highly active antiretroviral therapy on progression of HIV disease and its relationship to CD4 and viral load. AIDS 14: 2129-2136.

15. Waters L, Sabin CA (2011) Late HIV presentation: epidemiology, clinical implications and management. Expert Rev Anti Infect Ther 9: 877-889.

16. Chen LF, Hoy J, Lewin SR (2007) Ten years of highly active antiretroviral therapy for HIV infection. Med J Aust 186: 146-151.

17. Richardson ET, Collins SE, Kung T, Jones JH, Hoan Tram K, et al. (2014) Gender inequality and HIV transmission: a global analysis. J Int AIDS Soc 17: 19035 .

18. European Centre for Disease Prevention and Control (2013) Migrant health: Sexual transmission of HIV within migrant groups in the EU/EEA and implications for effective interventions. Stockholm.

19. Del Amo J, Likatavičius G, Pérez-Cachafeiro S, Hernando V, González C, et al. (2011) The epidemiology of HIV and AIDS reports in migrants in the 27 European Union countries, Norway and Iceland: 1999-2006. Eur J Public Health 21: 620-626.

20. Prejean J, Song R, Hernandez A, Ziebell R, Green T, et al. (2011) Estimated HIV incidence in the United States, 2006-2009. PLoS One 6: e17502.

21. Le Vu S, Le Strat Y, Barin F, Pillonel J, Cazein F, et al. (2010) Populationbased HIV-1 incidence in France, 2003-08: a modelling analysis. Lancet Infect Dis 10: 682-687.

22. World Health Organization (2014) Consolidated guidelines on HIV prevention, diagnosis, treatment and care for key populations.

23. Briem H, Thorsteinsson SB, Gudmundsson S, Erlendsson K, Love A (1996) The epidemiology of AIDS in Iceland. The first ten years. Laeknabladid 82: 21-31.

24. Löve A, Chen M, Sällberg M (2000) Changing profile of HIV-1 serotypes in Iceland during 1989-96. Scand J Infect Dis 32: 445-446.

25. http://statice.is/Statistics/Population

26. European Centre for the Epidemiological Monitoring of AIDS (1993) 1993 revision of the European AIDS surveillance case definition. AIDS Surveillance in Europe, Quarterly Report 37: 23-28.

27. Antinori A Coenen T, Costagiola D, Dedes N, Ellefson M, et al. (2011) Late presentation of HIV infection: a consensus definition. HIV Med 12: 61-64.

28. Hall HI, Song R, Rhodes P, Prejean J, An Q, et al. (2008) Estimation of HIV incidence in the United States. JAMA 300: 520-529.

29. Centers for Disease Control and Prevention (2012) Estimated HIV incidence in the United States, 2007-2010. HIV Surveillance Supplemental Report 17.

30. Norwegian Institute of Public Health (2014) HIV situation in Norway in 2013.

31. Statens Serum Institut HIV 2012. EPI - NYT 2013(44).

32. http://www.unaids.org/en/dataanalysis/knowyourresponse/ countryprogressreports/2012countries/ce_SE_Narrative_Report.pdf

33. European Centre for Disease Prevention and Control (2012) Country mission Finland: HIV, sexually transmitted infections, and hepatitis B and $\mathrm{C}$.

34. Bjorn-Mortensen K, Ladefoged K, Obel N, Helleberg M (2013) The HIV epidemic in Greenland--a slow spreading infection among adult heterosexual Greenlanders. Int J Circumpolar Health 72: 19558.

35. Beyrer C, Baral SD, van Griensven F, Goodreau SM, Chariyalertsak S, et al. (2012) Global epidemiology of HIV infection in men who have sex with men. Lancet 380: 367-377. 
Citation: Indridason H, Gudmundsson S, Karlsdottir B, Löve A, Briem H, et al. (2014) Long Term Nationwide Analysis of HIV and AIDS in Iceland, 1983-2012. J AIDS Clin Res 5: 387. doi:10.4172/2155-6113.1000387

Page 7 of 7

36. Amundsen EJ, Eskild A, Stigum H, Smith E, Aalen OO (2003) Legal access to needles and syringes/needle exchange programmes versus HIV counselling and testing to prevent transmission of HIV among intravenous drug users: a comparative study of Denmark, Norway and Sweden. Eur J Public Health 13: 252-258.

37. Kivela P, Krol A, Simola S, Vaattovaara M, Tuomola P, et al. (2007) HIV outbreak among injecting drug users in the Helsinki region: social and geographical pockets. Eur J Public Health 17: 381-386.

38. Volkow ND, Ding YS, Fowler JS, Wang GJ, Logan J, et al. (1995) Is methylphenidate like cocaine? Studies on their pharmacokinetics and distribution in the human brain. Arch Gen Psychiatry 52: 456-463.

39. Parran TV, Jasinski DR (1991) Intravenous methylphenidate abuse Prototype for prescription drug abuse. Arch Intern Med 151: 781-783.

40. Phillips A, Pezzotti P; CASCADE Collaboration (2004) Short-term risk of AIDS according to current CD4 cell count and viral load in antiretroviral drug-naive individuals and those treated in the monotherapy era. AIDS 18: 51-58.

41. Marks G, Crepaz N, Janssen RS (2006) Estimating sexual transmission of HIV from persons aware and unaware that they are infected with the virus in the USA. AIDS 20: 1447-1450.

42. Bhaskaran K, Hamouda O, Sannes M, Boufassa F, Johnson AM, et al (2008) Changes in the risk of death after HIV seroconversion compared with mortality in the general population. JAMA 300: 51-59.

43. Likatavicius G, Van de Laar M (2012) HIV and AIDS in the European Union, 2011. Euro Surveill 17.

44. Zoufaly A, an der Heiden M, Marcus U, Hoffmann C, Stellbrink H, et al. (2012) Late presentation for HIV diagnosis and care in Germany. HIV Med 13: 172-181.
45. Montlahuc C, Guiguet M, Abgrall S, Daneluzzi V, de Salvador F, et al. (2013) Impact of late presentation on the risk of death among HIV infected people in France (2003-2009). J Acquir Immune Defic Syndr 64: 197-203

46. Camoni L, Raimondo M, Regine V, Salfa MC, Suligoi B; regional representatives of the HIV Surveillance System (2013) Late presenters among persons with a new HIV diagnosis in Italy, 2010-2011. BMC Public Health 13: 281.

47. Helleberg M, Engsig FN, Kronborg G, Laursen AL, Pedersen G, et al. (2012) Late presenters, repeated testing, and missed opportunities in a Danish nationwide HIV cohort. Scand J Infect Dis 44: 282-288.

48. Valdiserri RO, Holtgrave DR, West GR (1999) Promoting early HIV diagnosis and entry into care. AIDS 13: 2317-2330.

49. Gardner EM, McLees MP, Steiner JF, Del Rio C, Burman WJ (2011) The spectrum of engagement in HIV care and its relevance to test-and-treat strategies for prevention of HIV infection. Clin Infect Dis 52: 793-800.

50. Campsmith ML, Rhodes PH, Hall HI, Green TA (2010) Undiagnosed HIV prevalence among adults and adolescents in the United States at the end of 2006. J Acquir Immune Defic Syndr 53: 619-624.

51. Branson BM, Handsfield HH, Lampe MA, Janssen RS, Taylor AW, et al. (2006) Revised recommendations for HIV testing of adults, adolescents, and pregnant women in health-care settings. MMWR Recomm Rep 55: $1-17$. 